Patrycja Haupt (phaupt@pk.edu.pl)

Katedra Kształtowania Środowiska Mieszkaniowego, Instytut Projektowania

Urbanistycznego, Wydział Architektury, Politechnika Krakowska

Sylwia Mochocka (smochocka@tu.kielce.pl)

Katedra Architektury i Urbanistyki, Wydział Budownictwa i Architektury, Politechnika

Świętokrzyska w Kielcach

Małgorzata Wijas (wijasm@tu.kielce.pl)

Katedra Architektury i Urbanistyki, Wydział Budownictwa i Architektury, Politechnika Świętokrzyska

\title{
Inicjatywy mieszkańców realizowane dzięki współpracy pomiędzy samorządem, uczelnią \\ a środowiskiem gospodarczym \\ - doświadczenia i szanse
}

\section{Initiatives of inhabitants implemented \\ by cooperation between authorities, university and business environment \\ - experiences and opportunities}

\begin{abstract}
Streszczenie
W artykule podjęto tematykę drobnych inicjatyw podejmowanych przez mieszkańców osiedli mieszkaniowych, służących poprawie jakości środowiska ich życia. Omówione zostały formy inicjatyw, inicjacji oraz finansowania, a także metody realizacji przy współpracy z uczelniami wyższymi, organizacjami, jednostkami komercyjnymi i samorządowymi. Analizie poddano efekty tych działań zarówno przestrzenne, jak i społeczne. Na podstawie doświadczeń w realizacji projektu „Budka na książki”, prowadzonego przez Katedrę Kształtowania Środowiska Mieszkaniowego Instytutu Projektowania Urbanistycznego Wydziału Architektury Politechniki Krakowskiej we współpracy z samorządem - Wydziałem Rewitalizacji Urzędu Miasta Krakowa, omówiono możliwości i zagrożenia w realizacji takich przedsięwzięć.
\end{abstract}

Słowa kluczowe: inicjatywy mieszkańców, przestrzeń publiczna, rehabilitacja osiedli mieszkaniowych

Abstract

The paper addresses the issue of small initiatives undertaken by inhabitants of housing estates to improve the quality of their living environment. The forms of initiatives, initiation and funding were discussed, as well as methods of implementation in cooperation with universities, organizations, commercial entities and self-government units. The effects of both spatial and social measures were analyzed. On the basis of experience in the implementation of the project "Bookshelves" conducted by the Department of Housing Development of the Institute of Urban Design, Cracow University of Technology in cooperation with the self-government of the Revitalization Department of the Cracow City Council discussed possibilities and threats in the implementation of such projects.

Keywords: inhabitants' initiatives, public space, urban renewal 


\section{WPROWADZENIE}

Realizacja przedsięwzięć, takich jak małe inicjatywy obywatelskie, jest procesem złożonym z kolejnych etapów angażujących wiele podmiotów, od fazy powstania pomysłu do jego urzeczywistnienia. Niejednokrotnie wymaga zaangażowania wielu współpracujących ze sobą organizacji, aby idea mieszkańca mogła zostać przedstawiona szerszemu gronu odbiorców, doprecyzowana, sfinansowana, a następnie wprowadzona w życie. Wspólne działania samorządu, uczelni, organizacji zewnętrznych i podmiotów gospodarczych na rzecz społeczności niosą ze sobą zarówno korzyści, jak i zagrożenia na każdym z etapów realizacji zaplanowanych zadań. Celem artykułu jest wskazanie możliwości realizowania drobnych projektów aktywizujących społeczność lokalną w przestrzeni publicznej, a także analiza potencjału współpracy pomiędzy jednostkami samorządowymi, akademickimi, środowiskiem gospodarczym i mieszkańcami w podnoszeniu jakości środowiska miejskiego.

\section{POMYS - INICJATYWA}

Początkiem współpracy pomiędzy samorządem a innymi jednostkami zewnętrznymi, takimi jak podmioty gospodarcze, organizacje, uczelnie wyższe, często stanowi pomysł mieszkańca, który przeradza się w inicjatywę społeczności lokalnej. Miejsce zamieszkania to obszar codziennych kontaktów, interakcji, tworzenia się relacji sąsiedzkich. Z doświadczeń w organizacji spotkań wspólnotowych, warsztatów aktywizacji mieszkańców ${ }^{1}$, wreszcie obserwacji życia osiedlowego ${ }^{2}$ wynika potrzeba komunikacji i działań w zakresie poprawy własnego środowiska. Przejawia się ona w postaci krytyki otaczającej rzeczywistości, ale coraz częściej zdarza się myślenie konstruktywne, w wyniku którego powstaje pomysł na poprawę konkretnych aspektów codziennego życia, dotykających konkretnej osoby, która reprezentatywna jest zwykle dla pewnej grupy społecznej mieszkańców. Idea taka zwykle ma potencjał trafnego rozwiązania problemów, konfliktów lub po prostu ułatwienia i uatrakcyjnienia codziennych aktywności. Szansą na pojawianie się nowych rozwiązań są warsztaty mieszkańców. Organizowane dzięki współpracy samorządu z partnerami (przedstawicielami środowiska naukowego, biznesowego, organizacjami) są miejscem szczegółowej diagnozy potrzeb, dyskutowania możliwych rozwiązań, przedstawiania ich szerszemu gronu odbiorców. Korzyści płynące ze współpracy na tym etapie kształtowania inicjatyw polegają na możliwości wykorzystania doświadczenia organizacji w realizowaniu podobnych przedsięwzięć, wiedzy fachowej ekspertów środowiska naukowego oraz praktycznych rozwiązań oferowanych przez biznes. Warsztaty można tutaj traktować jako ogólny model współpracy, modyfikowany do potrzeb konkretnej społeczności i lokalizacji.

Aby przekształcić pomysł w inicjatywę, musi przybrać on realne kształty konkretnego rozwiązania, popieranego przez mieszkańców i jednocześnie akceptowanego przez zaangażowanych decydentów. Kolejną fazą jest poszukiwanie możliwości wprowadzenia go w życie. 


\section{FINANSOWANIE - REALIZACJA}

Możliwości finansowania projektu zależne są od specyfiki samego założenia, jak i podmiotu go realizującego. Często wykonywane są one w ramach inwestycji budżetu obywatelskiego, niejednokrotnie wymagają współpracy pomiędzy podmiotami. Jej formy prześledzono na podstawie inicjatyw związanych z rozpowszechnianiem i udostępnianiem książek w kraju i na świecie.

Open Air Library, Magdeburg. W 2005 roku mieszkańcy opuszczonego centrum jednej z dzielnic Magdeburga, Salbke, w ramach warsztatów aktywizacyjnych, zainicjowanych przez miasto, zbudowali model obiektu w skali 1:1, używając skrzynek na piwo. W ciągu dwóch dni powstał budynek i zgromadzono książki na jego wyposażenie. Akcja ta pokazała, jak duże zainteresowanie wśród mieszkańców uboższych dzielnic mogą budzić takie inicjatywy. Cztery lata później na zlecenie władz miasta wybudowano w tym miejscu pawilon otwartej biblioteki. Powstał on w 2009 roku jako projekt partycypacyjny, zrealizowany przez biuro KARO Architekten przy udziale przedstawicieli lokalnej społeczności³. Inspiracją dla formy, którą częściowo wykonano zgodnie z pierwotnym modelem ze skrzynek na piwo, była zakładka. Od 2006 roku projektem zainteresowały się władze federalne i od tego czasu finansowany jest on ze środków budżetowych przeznaczonych na badania jako projekt pilotażowy przeznaczony do powielenia w innych miastach.

Vineyard Library, Ghent. Podczas festiwalu sztuki w 2012 roku powstała jedna z pierwszych nietypowych publicznych bibliotek. Zaprojektowana przez włoskiego artystę Massimo Bartoliniego na festiwal sztuki pod hasłem: Track: A Contemporary City Conversation ${ }^{4}$ instalacja składa się z 12 regałów, stojących na otwartym powietrzu, będących przedłużeniem linii winorośli. Zlokalizowano ją w ogrodach winnych opactwa świętego Piotra w belgijskiej Gandawie. Takie umiejscowienie konstrukcji artysta uzasadnia: ksiq̨żki - podobnie jak wino - moga poszerzać umys $\uparrow^{5}$. Obszar winnicy jest publicznie dostępny, a z księgozbioru można korzystać na zasadzie drobnych datków bądź wymiany. Nowatorskie wyobrażenie biblioteki, zaproponowane przez artystę, stało się inspiracją dla kolejnych projektów powstających, nie tak jak w przypadku Belgii, na zlecenie organizatorów festiwalu ze środków na wspieranie kultury, ale przy współpracy z lokalnymi społecznościami.

Little Free Library, Nowy York. Projekt małej, darmowej biblioteki ${ }^{6}$ powstał z inicjatywy organizacji non-profit "The Architectural League of New York", która zrzesza artystów działających w dziedzinie architektury i urbanistyki oraz pokrewnych, czuwając nad artystyczną stroną wykonywania zawodu, oraz "PEN World Voices Festival", organizującej coroczny festiwal literacki. Zadaniem Little Free Library jest łączenie lokalnych architektów i organizacji społecznościowych dolnego Manhattanu w celu wspólnej realizacji małych punktów wymiany książek. Działania rozpoczęto w 2013 roku podczas Ideas City Festival ${ }^{7}$. Rozpisano przetarg na wykonanie projektów obiektów małej architektury, które miały zostać zrealizowane, a następnie udostępnione do użycia przez inne społeczności lokalne. Dokumentację można 
pobrać ze strony organizatora przedsięwzięcia. Dzięki takiej współpracy można było rozszerzyć obszar oddziaływania projektów, gdyż bliźniacze punkty wymiany książek powstały np. w Atenach. Projektowi przypisano trzy główne cele - budowanie społeczności, wspieranie kreatywności i inspirowanie czytelników. Mogą być one realizowane dzięki stałej współpracy organizacji przy zarządzaniu i finansowaniu działań. Obecnie, według badańn ${ }^{8}$, na terenie Stanów Zjednoczonych znajduje się ponad 50 tysięcy takich punktów, a ruch dotarł do więcej niż 70 innych krajów. Analizy wskazują jednak, że większość z nich znajduje się w dzielnicach zamieszkałych przez osoby o wyższych dochodach i wykształceniu, a mieszkańcy osiedli o niższym statusie społecznym nie są zainteresowani korzystaniem ani z tego rozwiązania, ani z tradycyjnych bibliotek.

The Public Collection, Indianapolis. W sierpniu 2015 roku nastąpiło oficjalne otwarcie projektu Rachel M. Simon, związanej z Herron School of Art and Design, zarządzającej Indianapolis Museum of Art. Miał on na celu publiczne udostępnianie książek w społecznościach o niskim dochodzie, gdzie według badań ${ }^{9}$, po odpowiednią dla swego wieku pozycję sięga 1 na 300 dzieci. Innowacyjną cechą działań jest próba powiązania literatury ze sztuką, dzięki zleceniu zaprojektowania obiektów małej architektury działającym lokalnie artystom. Od 2015 roku powstało tam 8 pawilonów - mebli urbanistycznych, służących wymianie książek w miejscach publicznie dostępnych ${ }^{10}$.

Zrealizowanie przedsięwzięcia było możliwe dzięki współpracy pomiędzy fundacjami Herbert Simon Family Foundation, Indiana Community Foundation, a także firmą Art Strategies, zarządzającą projektami, i kuratorem sztuki oraz biblioteką The Indianapolis Public Library, która dostarcza książki na potrzeby projektu. Dzięki tak szerokiej współpracy możliwe było zaangażowanie lokalnych artystów, a także sfinansowanie budowy oraz funkcjonowania punktów wymiany książek.

Book Stop Project, Manila, Filipiny. Projekt mobilnego miejsca wymiany książek dla jednej z najbardziej mobilnych społeczności miejskich globu przygotowała pracownia WTA Architecture and Design ${ }^{11}$. Istotą nagrodzonego w 2016 roku w Berlinie podczas World Architecture Festival w kategorii „Small Projects" projektu było stworzenie nowej definicji biblioteki, będącej w stanie przyciągnąć współczesnych czytelników oraz promować czytelnictwo wśród kolejnych pokoleń. Wzorując się na sposobach z korzystania z informacji w sieci internetowej, gdzie użytkownicy dynamicznie przenoszą się ze strony na stronę, stworzono formę sieci przenośnych pawilonów, w których udostępniane są książki. Obiekty architektoniczne mają formę portalu, w którego wnętrzu umieszczono półki. Pod stalową konstrukcją zadaszenia zlokalizowano również miejsca do siedzenia, umożliwiające zatrzymanie się w nim na dłużej. Jeden z nich przybrał nawet formę mobilnego amfiteatru, pod którym znajduje się pawilon.

Projekt spełnia trzy podstawowe grupy zadań: społeczne - skupiające się na potrzebie bezpośredniego kontaktu i interakcji mieszkańców, badawcze - polegające na mierzeniu aktywności i sposobu wykorzystania obiektu oraz księgozbioru, a także rozwijanie prototypu funkcjonalnego współczesnej biblioteki przez badanie zachowań użytkowników. 
Sieć pawilonów bibliotecznych powstała dzięki współpracy pomiędzy pomysłodawcą - architektem Williamem Ti, Jr., pracującym dla WTA, a mieszkańcami i entuzjastami. Do propagacji idei włączyła się także światowa organizacja non-profit szerząca kulturę i język hiszpański - Instituto Cervantes w Manili. Projekt finansowany jest ze środków partnerów - darczyńców, którzy mogą się zgłaszać do koordynującej projekt pracowni WTA. Wiadomości, książki i darowizny na rzecz inicjatywy można przekazywać za pomocą mediów społecznościowych. Pomimo ogromnego międzynarodowego sukcesu projektu agencje rządowe odmówiły jego wspierania.

Weź ksiq̨żkę, zostaw ksiq̨żkę, Gogolin. Mieszkańcy miast, w których wprowadzono budżet obywatelski, mają możliwość uzyskania środków na realizację ogólnodostępnych projektów. Realizacją takiego zadania zajmuje się samorząd. Pole do współpracy jest tutaj dość nietypowe, gdyż władze lokalne niejako pośredniczą w realizacji danego przedsięwzięcia według wizji pomysłodawcy. Taki właśnie sposób finansowania pomysłu wybrali mieszkańcy Gogolina. Wzorując się na projekcie „Little Free Library”, przedstawili oni założenia przedsięwzięcia, polegającego na utworzeniu punktów wymiany książek w formie darmowych plenerowych biblioteczek, usytuowanych w popularnych miejscach spędzania wolnego czasu, przy parkach i placach zabaw ${ }^{12}$. Zaplanowano realizację 7 takich obiektów. Główne założenia projektu to kreacja atrakcyjnej przestrzeni dla miłośników literatury, promocja czytelnictwa i kultury, ale także integracja społeczności, która ma współtworzyć zasoby budek. Wśród korzyści płynących z powstania punktów darmowej wymiany książek wskazywano również szansę na promowanie swojej działalności wśród lokalnych twórców. Pierwsze trzy obiekty zrealizowano w maju 2017 roku, kolejne mają powstać, jeśli pomysł się przyjmie. Mają one być finansowane przez samorząd. Rozważa się również zlokalizowanie ich na terenach wiejskich ${ }^{13}$. Współpraca pomiędzy władzami, mieszkańcami, a także biblioteką pozwoliła na wyposażenie biblioteczek, a w przyszłości na sprawne funkcjonowanie i testowanie rozwiązania.

Budka na ksiq̨żki, Kraków. Idea projektu realizowanego przez Katedrę Kształtowania Środowiska Mieszkaniowego Instytutu Projektowania Urbanistycznego Wydziału Architektury Politechniki Krakowskiej we współpracy z Wydziałem Rewitalizacji Urzędu Miasta Krakowa, jako część Pilotażowego Projektu Rehabilitacji Zabudowy Blokowej, zrodziła się w 2013 roku. Podczas warsztatów „Future City Game - Gra Miasto Przyszłości” ${ }^{14}$, organizowanych dla mieszkańców przez Urząd Miasta Krakowa we współpracy z organizacją British Council na terenie osiedla Olsza II, mieszkanka osiedla w ramach swojego projektu zaproponowała rozwiązanie wykorzystujące największy potencjał możliwy podczas procesu rehabilitacji tego obszaru - jego mieszkańców i zieleń. Grupa opracowała ideę projektu małych, darmowych biblioteczek, gdzie mieszkańcy mogliby wymieniać się książkami. Pomysł ten został rozwinięty podczas prac warsztatowych studentów Wydziału Architektury Politechniki Krakowskiej oraz Wydziału Budownictwa i Architektury Politechniki Świętokrzyskiej, a także Wydziału Informatyki, Elektroniki i Telekomunikacji Akademii Górniczo-Hutniczej w Krakowie pod kierunkiem członków Koła Naukowego Projektowania Zrównoważonego pod opieką 
dr hab. inż. arch. Justyny Kobylarczyk, prof. PK oraz dr inż. arch. Patrycji Haupt. W ogólnopolskich warsztatach w formule konkursowej, które odbyły się 6 listopada 2015 roku, wzięło udział czternaście kilkuosobowych zespołów. Jury, złożone z akademików oraz architektów z UMK, wyłoniło cztery zwycięskie prace. Następnie zostały one publicznie przedstawione podczas konsultacji społecznych w formie spotkania warsztatowego, które odbyło się 9 grudnia 2015 roku w budynku Społecznego Gimnazjum nr 8 Społecznego Towarzystwa Oświatowego. Od 2016 roku studenci Koła Naukowego Projektowania Zrównoważonego przygotowywali projekty prototypów zwycięskich rozwiązań, które 3 czerwca 2017 roku zostały zaprezentowane mieszkańcom dzielnicy podczas Dni Dzielnicy III Prądnik Czerwony na stadionie KS „Wieczysta”. Mogli oni obserwować, jak powstają obiekty, a później brać udział w plebiscycie organizowanym przez Wydział Rewitalizacji UMK na najlepiej spełniający swoje zadanie prototyp. W lipcu 2017 roku przeniesiono ekspozycję na teren osiedla, gdzie mieszkańcy mogli korzystać z budek na książki przez trzy tygodnie, wymieniając tam książki, oceniając, który pomysł najlepiej wpisuje się w charakter ich miejsca zamieszkania. Plebiscyt był kontynuowany, a jego wyniki ogłosiła podczas imprezy plenerowej Elżbieta Koterba - II Zastępca Prezydenta Miasta Krakowa ds. rozwoju miasta. Zwycięski projekt, wykonany przez zespół studentów i absolwentów Politechniki Krakowskiej oraz Świętokrzyskiej: Katarzynę Płonkę, Grzegorza Krzemienia, Wiktorię Stępczyńską i Barbarę Wojnar, będzie realizowany w formie docelowej i stanie na terenie osiedla w 2018 roku. Szeroka współpraca między środowiskiem akademickim, władzami lokalnymi, firmami zewnętrznymi oraz organizacjami obywatelskimi w procesie partycypacyjnym na wszystkich etapach realizacji projektu pozwoliła na uatrakcyjnienie przestrzeni osiedla i zaangażowanie mieszkańców, aktywizując tym samym społeczność lokalną.

\section{PODSUMOWANIE I WNIOSKI}

Charles Montgomery w swojej książce Miasto szczęśliwe ${ }^{15}$ opisuje na przykładach z całego świata poszukiwanie istoty miasta. Potencjał widzi on, podobnie jak Jan Gehl ${ }^{16}$, w przestrzeniach publicznych. Ich obraz i charakter uważa za powiązany krzyżowo ze świadomością przynależności i aktywnością społeczności lokalnej. Opisuje ewolucję drogi od poczucia anonimowości mieszkańca do zaangażowania w społeczność, wskazując różne sposoby, na jakie można ten proces realizować. „Stojące przed nami wyzwanie polega na tym, by zmienić nie tylko metody budowania, lecz także sposób myślenia"17. Jedną z metod na poprawę jakości środowiska miejskiego jest budowanie miejsca ${ }^{18}$ - przestrzeni przynależnej do danej społeczności, uwarunkowanej przez nią kulturowo.

Dla sukcesu takich przedsięwzięć kluczowe wydaje się znalezienie sposobu zaangażowania mieszkańców. Jak wykazały studia zrealizowanych projektów obiektów służących wymianie książek, współpraca pomiędzy środowiskami jest istotna, choć nie jest warunkiem 
koniecznym, co pokazuje przykład Manili. Przykłady polskie i europejskie wskazują jednak, że partnerstwo między samorządami, środowiskiem biznesowym i organizacjami publicznymi sprawia, iż realizacja i finansowanie takich inicjatyw jest łatwiejsze. Stwarza również większe szanse na zaangażowanie mieszkańców przez miękkie projekty i większą ilość instrumentów, jakie można w lokalnym środowisku zastosować.

Projekty finansowane komercyjnie związane są częściej z przestrzeniami publicznymi miasta, zwykle już dofinansowanymi - rozwijającymi się bądź zrewitalizowanymi. Te opierające się o współpracę docierają do społeczności lokalnych, które działań skierowanych na poprawę jakości życia najbardziej potrzebują. Jak pisze Markus Miessen, „W przeciwieństwie do sporów o metaproblemy lokalna skala może doprowadzić do postawienia konkretnych i konstruktywnych pytań. Skala pytania powinna być rozważana i opracowywana w odpowiedzi na potrzeby odbiorców (...)"19. Dzięki inicjatywom podejmowanym w ramach szerokiej, międzyśrodowiskowej współpracy stwarzane są możliwości działań właśnie w takiej, dopasowanej do kontekstu skali. Daje ona zatem szansę na rehabilitację enklaw w obszarach miasta, które ulegają stopniowej degradacji, przez uatrakcyjnienie przestrzeni i aktywizację oraz scalanie lokalnych społeczności. 


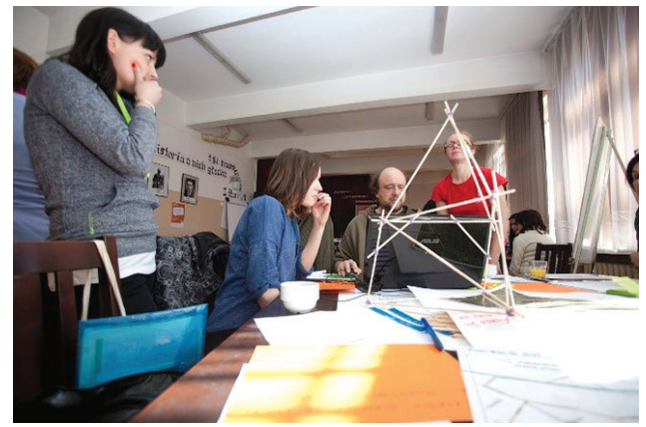

II. 1. Warsztaty „Future City Game”, 2013 (Wydział Rewitalizacji UMK)

III. 1. Workshops „Future City Game”, 2013

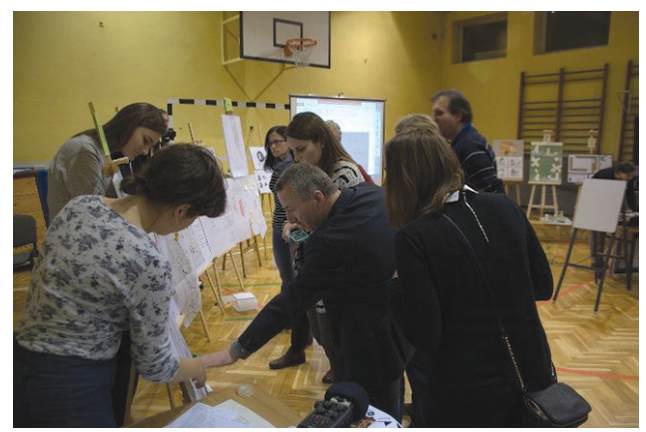

II. 3. Konsultacje projektów z mieszkańcami, 2016 (fot. autorki)

III. 3. Consultation with residents, 2016

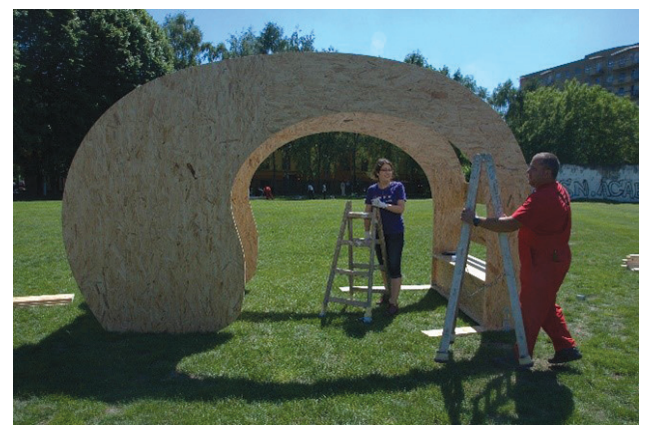

II. 5. Dni Dzielnicy III, 2017 (fot. autorki)

III. 5. District III Days, 2017

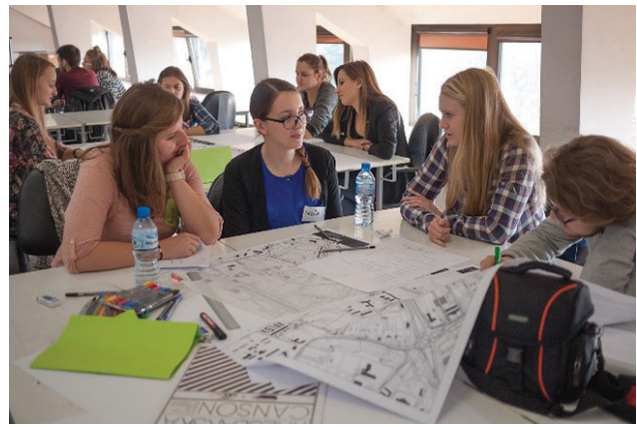

II. 2. Warsztaty projektowe „Budka na książki”, 2016 (fot. autorki)

III. 2. Design workshops „Budka na książki”, 2016

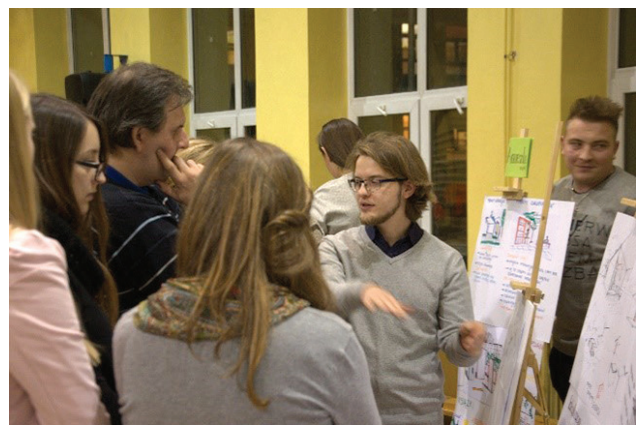

II. 4. Konsultacje projektów z mieszkańcami, 2016 (fot. autorki)

III. 4. Consultation with residents, 2016

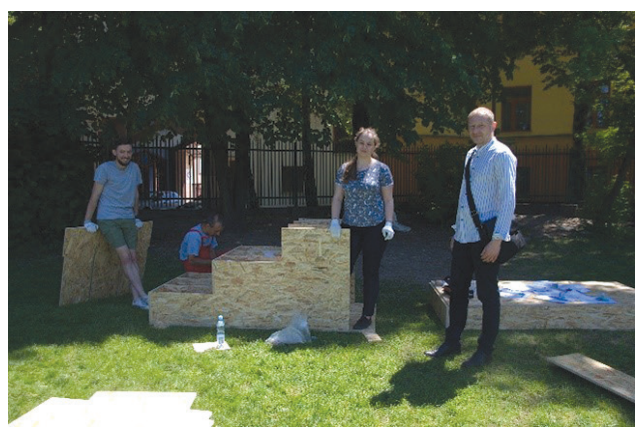

II. 6. Dni Dzielnicy III, 2017 (fot. autorki)

III. 6. District III Days, 2017 


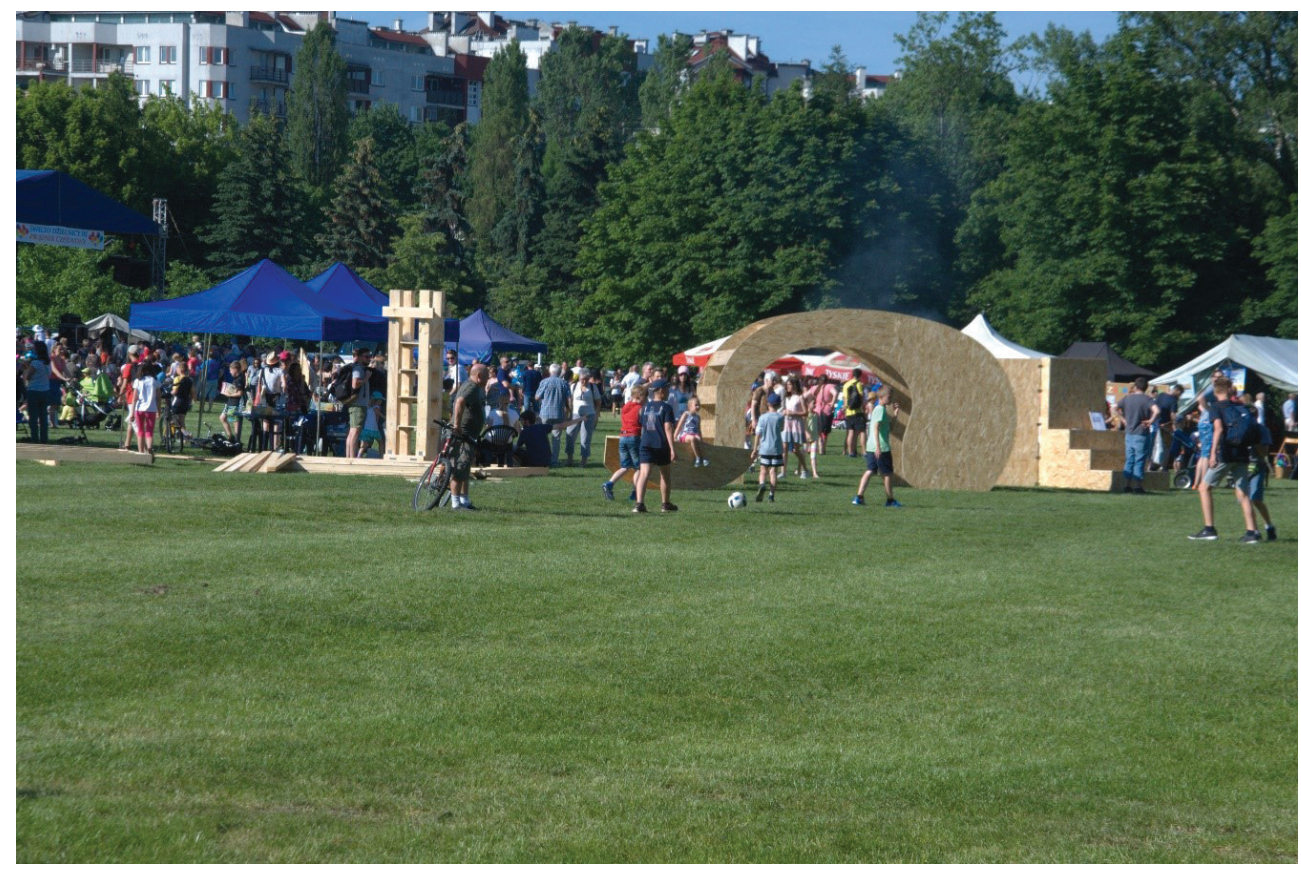

II. 7. Dni Dzielnicy III, 2017 (fot. autorki) III. 7. District III Days, 2017

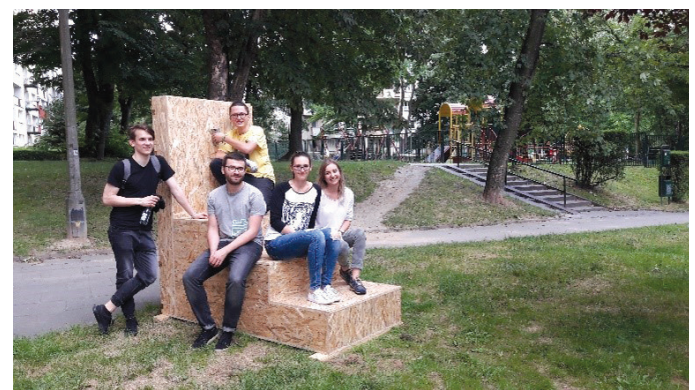

II. 8. Montaż prototypów Ugorek, 2017 (fot. autorki) III. 8. Mounting prototypes Ugorek, 2017

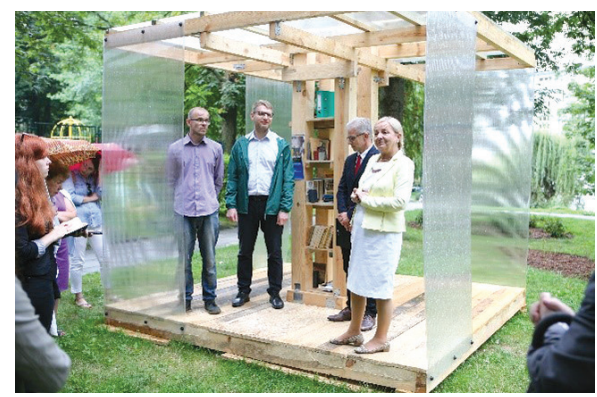

II. 9. Finał plebiscytu, 2017 (Wydział Rewitalizacji UMK) III. 9. The final of the plebiscite, 2017 


\section{PRZYPISY}

1 Future City Game, Active Citizens - działania partycypacyjne, metodologia warsztatów, opracowana przez British Council w ramach projektu "Active Cities", służąca aktywizacji mieszkańców I rozwiązywaniu konkretnych problemów, https://www.britishcouncil.us/ programmes/education/research-reports/creative-cities (dostęp: 2.08.2017).

2 Podczas przeprowadzania badań na potrzeby diagnozy funkcjonalno-przestrzennej osiedli Ugorek i Olsza II w ramach Pilotażowego Programu Rehabilitacji Zabudowy Blokowej na terenie Gminy Kraków, zrealizowany na podstawie umowy o współpracę pomiędzy Urzędem Miasta Krakowa a Politechniką Krakowską. J. Kobylarczyk et al., Diagnoza funkcjonalno-przestrzenna osiedli: Olsza II i Ugorek. Cz. I. Opracowanie eksperckie, Instytut Projektowania Urbanistycznego, Wydawnictwo Politechniki Krakowskiej, Kraków 2014.

3 Open Air Library / KARO Architekten, http://www.archdaily.com/39417/open-air-library-karo-architekten (dostęp: 2.08.2017).

4 Massimo Bartolini's Bookyard is an Outdoor Library in a Belgian Vineyard, http://inhabitat.com/massimo-bartolini\%E2\%80\%99s-bookyard-brings-together-a-belgian-vineyard-and-an-outdoor-library/ (dostęp: 2.08.2017).

5 Biblioteka w belgijskiej winnicy, http://booklips.pl/newsy/biblioteka-w-belgijskiej-winnicy/ (dostęp: 2.08.2017).

6 Little Free Library LTD, https://littlefreelibrary.org/ (dostęp: 2.08.2017).

7 Little Free Library/NYC, http://archleague.org/2013/07/little-free-library/ (dostęp: 2.08.2017).

8 Against Little Free Libraries, https://www.citylab.com/life/2017/05/the-case-against-littlefree-libraries/523533/ (dostęp: 2.08.2017).

9 Badania Mindy Taylor Ross [3].

10 Indy Library Provides Books for Artist-Designed Book Share Stations, http://www.indypl. org/about/news/2015-archives/indy-library-provides-books-artist-designed-book-sharestations/ (dostęp: 2.08.2017).

11 The Bookstop, http://www.wtadesignstudio.com/thebookstop (dostęp: 2.08.2017).

12 Projekt M2 - Budki na książki, http://gogolin.pl/8392/projekt-m2-budki-na-ksiazki.html (dostęp: 2.08.2017).

${ }^{13}$ Mieszkańcy wybrali, samorząd zrealizował. W Gogolinie stoją budki na książki, http:// radio.opole.pl/101,197698, mieszkancy-wybrali-samorzad-zrealizowal-w-gogoli (dostęp: 2.08.2017).

${ }^{14}$ Future City Game jest metodologią opracowaną w Wielkiej Brytanii w ramach projektu British Council „Creative Cities”, polegającą na tym, że podczas dwu- lub jednodniowego spotkania, na które zaproszeni są różni interesariusze (mieszkańcy i specjaliści, tacy jak m.in. badacze społeczni, architekci, przedsiębiorcy, przedstawiciele organizacji pozarządowych oraz urzędnicy), wypracowywane są konkretne rozwiązania przestrzenne i funkcjonalne dla danego miejsca (np. zagospodarowanie parku) lub problemu powiązanego z miejscem 
(np. oferta domu kultury). W Krakowie stosowana podczas realizacji Pilotażowego Projektu Rehabilitacji Zabudowy Blokowej m.in. na osiedlach Ugorek i Olsza II oraz Azory, https:// www.britishcouncil.us/programmes/education/research-reports/creative-cities (dostęp: 2.08.2017).

${ }^{15}$ Ch. Montgomery, Miasto szczęśliwe, Wysoki Zamek, Kraków 2015.

16 J. Gehl, Life between Buildings. Using Public Space, Island Press 2011.

17 Ch. Montgomery, Miasto szczęśliwe, Wysoki Zamek, Kraków 2015, s. 436.

18 Yi-Fu Tuan, Przestrzeń i miejsce, Państwowy Instytut Wydawniczy, Warszawa 1987, s. 75.

19 M. Miessen, Koszmar partycypacji, bęc zmiana, Warszawa 2013, s. 235.

\section{BIBLIOGRAFIA}

Active Cities, https://www.britishcouncil.us/programmes/education/research-reports/creative-cities (dostęp: 2.08.2017).

Against Little Free Libraries, https://www.citylab.com/life/2017/05/the-case-against-little-free-libraries/523533/ (dostęp: 2.08.2017).

Art Strategies, http://www.indystar.com/story/life/2015/08/28/indy-book-sharing-stations-combine-art-literacy/71285156/ (dostęp: 2.08.2017).

Biblioteka w belgijskiej winnicy, http://booklips.pl/newsy/biblioteka-w-belgijskiej-winnicy/ (dostęp: 2.08.2017).

Gehl J., Life between Buildings. Using Public Space, Island Press 2011.

Kobylarczyk J., Schneider-Skalska G., Haupt P., Racoń-Leja K., Diagnoza funkcjonalno-przestrzenna osiedli: Olsza II i Ugorek. Cz. I. Opracowanie eksperckie, Instytut Projektowania Urbanistycznego, Wydawnictwo Politechniki Krakowskiej, Kraków 2014.

Indy Library Provides Books for Artist-Designed Book Share Stations, http://www.indypl.org/ about/news/2015-archives/indy-library-provides-books-artist-designed-book-share-stations/ (dostęp: 2.08.2017).

Little Free Library LTD, https://littlefreelibrary.org/ (dostęp: 2.08.2017).

Little Free Library/NYC, http://archleague.org/2013/07/little-free-library/ (dostęp: 2.08.2017). Massimo Bartolini's Bookyard is an Outdoor Library in a Belgian Vineyard, http://inhabitat.com/massimo-bartolini\%E2\%80\%99s-bookyard-brings-together-a-belgian-vineyard-and-an-outdoor-library/ (dostęp: 2.08.2017).

Miessen M., Koszmar partycypacji, bęc zmiana, Warszawa 2013.

Mieszkańcy wybrali, samorząd zrealizował. W Gogolinie stoją budki na książki, http://radio.opole.pl/101,197698,mieszkancy-wybrali-samorzad-zrealizowal-w-gogoli (dostęp: 2.08.2017).

Montgomery Ch., Miasto szczęśliwe, Wysoki Zamek, Kraków 2015. 
Open Air Library / KARO Architekten, http://www.archdaily.com/39417/open-air-library-karo-architekten (dostęp: 2.08.2017).

Projekt M2 - Budki na książki, http://gogolin.pl/8392/projekt-m2-budki-na-ksiazki.html (dostęp: 2.08.2017).

The Bookstop, http://www.wtadesignstudio.com/thebookstop (dostęp: 2.08.2017).

Tuan Yi-Fu, Przestrzeń i miejsce, Państwowy Instytut Wydawniczy, Warszawa 1987. 